\title{
Ontogenetic Allometry of Body Height and Body Mass of Girl in Baduy, Indonesia
}

\author{
Eneng Nunuz Rohmatullayaly ${ }^{1}$, Alex Hartana ${ }^{1}$, Yuzuru Hamada², Bambang Suryobroto ${ }^{1 *}$ \\ ${ }^{1}$ Department of Biology, Faculty of Mathematics and Natural Science, Bogor Agricultural University, Kampus IPB Dramaga, Bogor, \\ Indonesia \\ ${ }^{2}$ Section of Evolutionary Morphology, Primate Research Institute, Kyoto University Inuyama, Aichi 484-8506, Japan
}

ARTICLE INFO

Article history:

Received May 1, 2018

Received in revised form June 15, 2018

Accepted July 1, 2018

\section{KEYWORDS:}

ontogenetic allometry,

growth,

menarche,

body fat,

body size,

Baduy

\begin{abstract}
Several small-scale populations exhibited phenotypic plasticity whereby growth spurt of body height occurred much earlier than age at menarche and this was not followed by same early spurt of body weight. This leads to question whether growth trajectory of stature follow the same growth trajectory of body mass and whether the trajectory itself is associated to sexual maturity. We evaluated developmental plasticity observed in Baduy girl, a traditional population in Indonesia, in facing strenuous environmental and biocultural conditions. We measured stature and body mass cross-sectionally. We determined age at menarche as population average of age of girls that had already got their first menstruation. Growths of body fat and weight followed a same mode and timing and their spurts pivoted on the age at menarche. In contrast, growth spurt of body height occurred four years earlier than menarche and velocity curve of body linearity progressed in opposite direction to that of body ponderality. The prevailing poor nutrition and high physical activity elicited principle of ontogenetic allometry to synchronize the acceleration and deceleration of growths in body linearity and ponderality whereby growth in body height functions to reach the body size target and to provide skeletal framework for development of body mass. The biocultural conditions lead to slow bodily growth rate with low spurt resulting in the characteristics of Baduy girl that was small in size and late in both sexual maturity and full-grown ages.
\end{abstract}

\section{Introduction}

Growth trajectory of body size charts the health and nutritional statuses of a population (Eveleth and Tanners 1990; Bogin 1999; Rogol et al. 2000; Walker et al. 2006; Migliano et al. 2007; Kramer and Greaves 2010; Urlacher et al. 2016). Healthy environment and better nutrition provide children with resources to grow faster and taller compare to children living in poor condition (Eveleth and Tanners 1990; Bogin 1999; Adair 2001; Walker et al. 2006). In this optimum bioculture, the timing of female sexual maturity is matched to and provides a pivot for adolescent growth spurts in body mass and stature. In 2-compartment biomass model consisting of fat and lean masses, a threshold of body fat proportion relates to the endocrinal hypothalamic-pituitary-gonadal (HPG) axis and also involves in the regulation of the hypothalamic-pituitary-adrenal (HPA) axis feedback mechanism in triggering menarche (Frisch and Revelle 1969, 1970, 1971a, b; Frisch et al. 1973; Frisch and McArthur 1974; Frisch 1975; Malina et al. 2004; Ebling 2005; Kaplowitz 2007). Menarche is also closely

* Corresponding Author.

E-mail Address: suryobroto@ipb.ac.id related to skeletal development via adrenocortical secretion of anabolic androgens in HPA axis. Skeletal segments add up to body height and several growth studies found that age at peak growth velocity (APV) of this linear feature of body is reached close to the timing of menarche (Frisch and Revelle 1969; Ellison 1981, 1982; Chang et al. 2000; Malina et al. 2004).

In contrast, poor living condition modulates stages and rates of body development to restrict the adult size (Walker et al. 2006; Migliano et al. 2007; Kramer and Greaves 2010; Kawulur et al. 2012, 2013). For instance, girls living in populations that have low energy availability and environmental constraints grow slowly with low spurt leading to late menarche, delay growth cessation, and small adult size (Frisch 1975; Eveleth and Tanners 1990; Bogin 1999; Gurven and Walker 2006; Walker et al. 2006). Furthermore, small-scale populations exhibited phenotypic plasticity whereby APV of body height was reached much earlier than age at menarche and this was not followed by same early APV of body weight (Walker et al. 2006; Kramer and Greaves 2010). This leads to question whether growth trajectory of stature follow the same growth trajectory of body mass and whether the trajectory itself is associated to sexual maturity. The base of this question pertains to the ontogenetic 
allometrical principle that governs differential agerelated changes in components that make up the total size of organism (Gould 1966).

There were few reports that specifically employ allometric perspective on age-related changes of stature and body mass and its covariation to menarche. This is understandable given nutritional improvement in well-developed societies diminished ethnic differences in growth of body height and weight and leads to stereotypical generalization in interpreting life history data. We should therefore seek the answer to the above question to populations that are local and less or not involved in the network of social services, economics, and politics. Here we report developmental plasticity observed in Baduy, a traditional population in Indonesia (Wessing and Barendregt 2005), in facing strenuous environmental and biocultural conditions (Ichwandi and Shinohara 2007).

Baduy people inhabit isolated area (around 5100 ha) of mountainous rainforest in Kanekes Village, Lebak Regency, Indonesia. Main topography of their area is hilly with an average slope $49.1 \%$, average annual rainfall $4000 \mathrm{~mm}$, and soil type clay latosol (Iskandar and Ellen 1999; Ichwandi and Shinohara 2007). The tradition stipulates strict socio-cultural conducts and daily obligatory duties to protect the sustainability of swidden farming in the mineral-poor and erosion-risk terrain. Their agricultural practice restricts mechanical tool merely to digging sticks and chopping- and finger-knives. In complement to prohibition to any modern farming technologies, the religious beliefs preclude external influences and ban the formal education (Ichwandi and Shinohara 2007; Erwinantu 2012; Hasman and Reis 2012). The socio-cultural isolation and endogamous marriage system make their life history unique, so in recording their growth trajectory we expect to get insight into principles that govern their adaptation.

We found that in Baduy girl the growths of body mass components, i.e. body fat and weight, followed a same mode and timing and their APVs pivoted on the age at menarche. In contrast, APV of body height occurred four years earlier than menarche and velocity growth curve of body linearity progressed in opposite direction to that of body ponderality. These phenomena reveal the principle of ontogenetic allometry in synchronizing the acceleration and deceleration of the growths of stature and body mass.

\section{Materials and Methods}

\subsection{Subject}

Cross-sectional interview and measurements were conducted in July to November 2011 and January to November 2014. Subjects were girls from 37 out of 61 hamlets totaling 312 individuals with age ranged from 4 to 26 years. Each subject or parent was explained about the purpose of this study, and if they agree to participate, they signed or thumb printed the informed consent form. The interview and measurement protocols were approved by Office of National Unity, Politics and Public Protection of Lebak Regency and the research followed the regulation attached on the permit letter (No.300/246-Kesbang Pol and Linmas/ VI/2013). This research abode by the Baduy customs outlined by Head of Kanekes Village.

\subsection{Birth Date}

Age was calculated as the number of days since birth date to the date of interview. We set age class in a one-year interval and determined each age class to the nearest birth date of the relevant year. However, most subjects do not have birth date record. For girls with unknown birthdate, we used the procedure outlined in Rohmatullayaly et al. (2017).

\subsection{Sexual Maturation}

Subjects for sexual maturation analysis were 151 girls; they were subset of the total sample. We determined age at sexual maturity as population average of age of girls that had already got their first menstruation. Given an age class, the menarcheal statuses of girls were identified. The menarche/nonmenarche events across the pre- to post-pubertal age classes follow yes/no binomial distribution and we used Generalized Linear Models (GLM) using probit link (Venables and Ripley 1999) to calculate the median age.

\subsection{Growth Velocity of Body Size}

There are accumulating evidences that indicate animals measure dimensions rather than cell number when they grow (Sprent 1972; Day and Lawrence 2000; Lecuit and Le Goff 2007). In measuring total size of organisms, the readily observed components are their length and mass. Present human biology research used stature (body height, $\mathrm{BH}$ ) as body length; it was measured with accuracy $1 \mathrm{~mm}$. Body mass was measured by weight (BW) with accuracy $100 \mathrm{~g}$. BW consists of two chemically distinct compartments: fat and lean masses (Frisch et al. 1973; Frisch 1975; Malina et al. 2004). Adipose cells produce leptin that directly affects the onset of puberty (Matkovic et al. 1997; Fechner 2002; Karapanou and Papadimitriou 2010). Therefore, in addition to BW, we also measured body fat to see how it developed in relation to sexual maturity. The body fat component was approached by measuring skinfold thickness at triceps (TS) and subscapular (SbS) points with accuracy $0.1 \mathrm{~mm}$ to reveal subcutaneous fat (Malina et al. 2004). Percentage of body fat (PBF) from total BW was estimated as $\mathrm{PBF}=1.33(\mathrm{TS}+\mathrm{SbS})-0.013(\mathrm{TS}+\mathrm{SbS})^{2}-$ 2.5 (Slaughter et al. 1988).

In allometric perspective, length is considered a linear whereas mass a cubic dimension (Gould 1966). We derived body linearity index (BLI) by scaling BH (in $\mathrm{cm}$ ) to cube root of $\mathrm{BW}$ (in $\mathrm{kg}$ ) and ponderal index (PI) by scaling $\mathrm{BW}$ (in $\mathrm{kg}$ ) to cubed $\mathrm{BH}$ (in $\mathrm{m}$ ). 
Each growth trajectory of BH, BW, PBF, BLI, and PI was estimated from $50^{\text {th }}$ percentile values of yearly cohort in the cross-sectional data. We used Generalized Additive Models for Location, Scale and Shape (GAMLSS) (Stasinopoulos and Rigby 2007) to predict the percentile. Annual velocities were calculated as increments between consecutive years and velocity curve was charted by linking midyear points. We identified two landmarks on each velocity curves. The first is APV that represents the growth spurt. The second is age at speed equaled zero when the girls got full growth; we consider this age as the adult age of each trajectory. In considering the sampling bias and secular effect, we approached the growth cessation at the nearest midpoints to the zero speed. All procedures were run on R software version 3.3.2 for Mac (R Development Core Team 2016).

\section{Results}

Half of Baduy girls reached sexual maturity at age 14.3 year (2.5-97.5\% range $11.5-17.2$ year; Figure $1 \mathrm{a}$ and b). The median age at menarche coincided with APVs of body fat and weight (Figure 1a). Before reaching APV 14.5 year, juvenile $\mathrm{PBF}$ followed an increasing growth path for ten years. At the spurt the PBF amounted to $20.5 \%$ of the total body weight. The growth rate then decreased reaching zero at age 23.5 year to get full-grown PBF 24.9\%. Prepubertal growth rate of BW also increased to attain maximum growth speed at 13.5 year $(32.1 \mathrm{~kg})$, one year before menarche; given the temporal resolution of one year in determining birth date and the positing of annual velocity point at midyear, the difference between APV of BW and age at menarche may be considered as non-significant. After that, the rate decreased to zero at 25.5 year reaching grown-up BW at $47.7 \mathrm{~kg}$. The increasingdecreasing path of growth velocities of PBF and BW shows that these two measurements of body mass followed a same mode and timing and their spurts were reflected on the age at menarche. Furthermore, the allometrically scaled body mass PI (Figure 1b) went after the same increasing-decreasing growth trend of PBF and BW though its maximum speed was reached a little bit later than age at menarche.

In contrast, Baduy girls got peak of $\mathrm{BH}$ growth velocity (10.5 year, $124.6 \mathrm{~cm}$; Figure 1a) four years earlier than menarche, that is, well before APVs of PBF and BW (Figure 1a). Comparing to ten years interval of increasing growth rate of body mass, $\mathrm{BH}$ experienced the increase for only six years prior to decreasing for 11 years passing menarche landmark (at $139.0 \mathrm{~cm}$ ) until fully developed (at $149.4 \mathrm{~cm}$ ) at 21.5 year. As well as growth spurt, the age at growth completion of BH was earlier than that of PBF (23.5 year) and BW (25.5 year). The gap between the courses of stature and body mass was further accentuated by differing growth path of body linearity BLI. While ponderal index increased at prepubertal age, growth speed of a

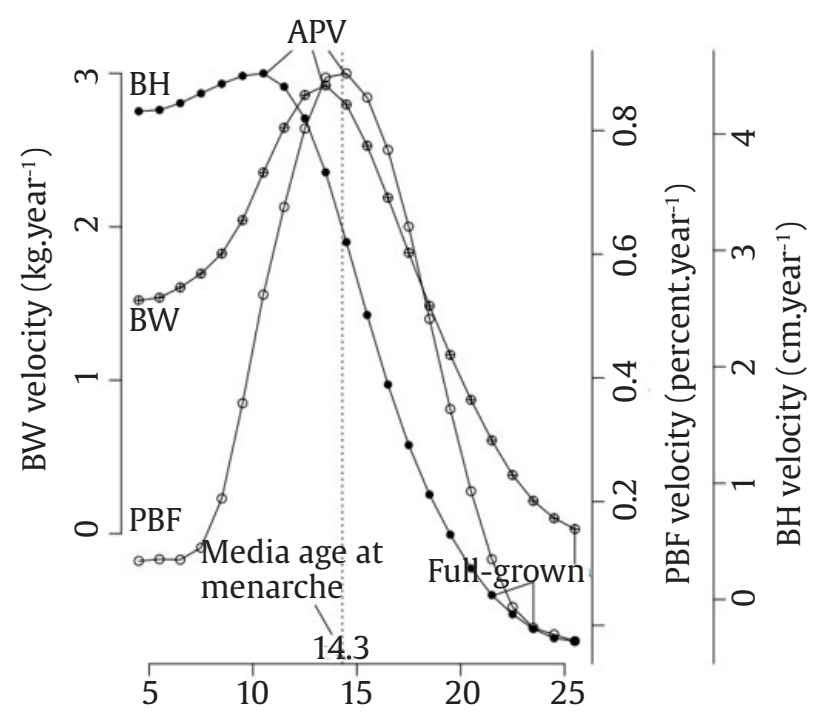

Age (year)

b

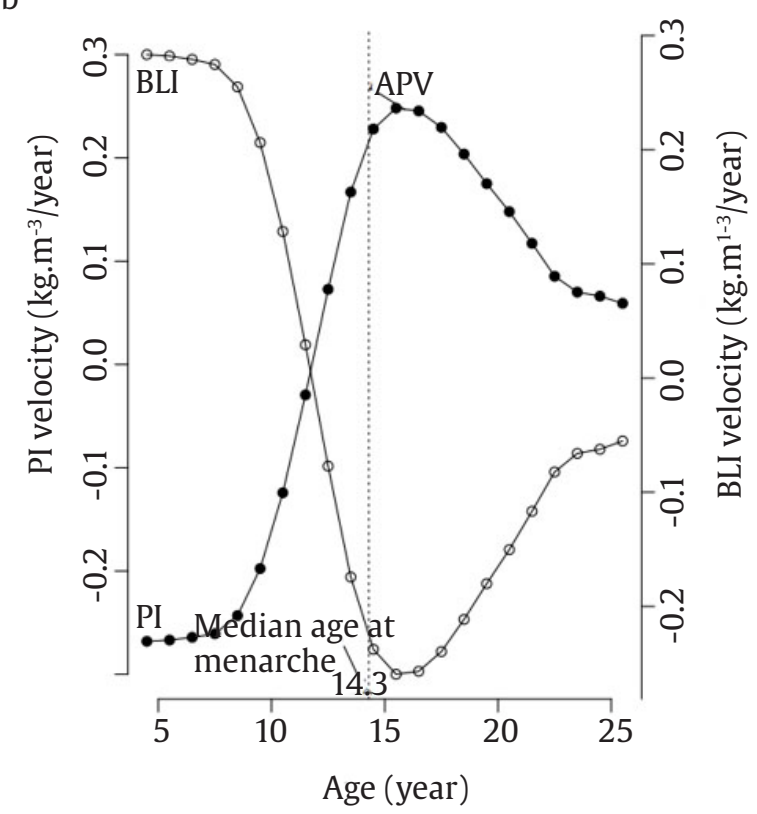

Figure 1. Median age at menarche and growth velocity of body size. (a) Growth speeds of body masses (fat and weight) firstly increased, reaching APVs at menarche before decreasing to zero at fullgrown. In contrast, BH reached APV four year in advance of menarche before continuing to decrease in following different pathway. (b) The allometrically scaled body mass PI went after the same increasing-decreasing growth trend of PBF and BW though its maximum speed was reached a little bit later than age at menarche. In contrast, growth speed of body linearity was decreasing before reversed around puberty so, instead of APV, growth of BLI had nadir of velocity at about one year after menarche before bounced back and plateau after 23.5 year. APV age at peak velocity, $\mathrm{BH}$ body height, BLI body linearity index, BW body weight, PBF percentage of body fat to total body weight, PI ponderal index 
body linearity was decreasing before reversed around puberty (Figure 1b). Instead of APV, growth of BLI had nadir of velocity at about one year after menarche before bounced back and plateau after 23.5 year. The increasing growth speed of BLI offset the decreasing growth rate of $\mathrm{BH}$. As it is expected, the allometrically scaled PI and BLI had growth rate routes that mirror image one another. These results shows that growth trajectory of BH was clearly dissociated from that of body mass.

\section{Discussion}

The dissociation and opposition in growth trends of body linearity and body ponderality reveals the synchronization of acceleration and deceleration between different growth rates of length and mass that make up the total size of organism. In light of this concept, the observed gap between the two growth trends would be meaningful if we interpret the growth of BH functions as to reach body size target and to provide skeletal framework for development of body mass. With this interpretation we think that metabolic costs of growth are divided into skeletal completion in advance of metabolic commitments to body weight and to reproductive maturation (Frisch 1972; Frisch and McArthur 1974; Kramer and Greaves 2010). Present results show that the target of total body size was determined by $\mathrm{BH}$ when completing to grow at 21.5 year, earlier than PBF and BW that continued to develop before reaching zero speed at 23.5 and 25.5 year, respectively. The parsing of metabolic cost can also be seen at puberty. Compared to other populations (Walker et al. 2006; Figure 2), APV of $\mathrm{BH}$ was reached early while reproductive maturity of Baduy girl can be considered as late. The early spurt of $\mathrm{BH}$ might be interpreted as to prepare skeletal build and the late APVs of PBF and BW represent the time needed for fat to grow to its critical proportion in triggering sexual maturation. The longer time to reach critical proportion for initiation of menarche was caused by slow growth rate and low growth spurt (Rohmatullayaly et al. 2017).

The mechanics of ontogenetic allometry leads to the characteristics of Baduy girl that was small in body size and late in both sexual maturity and full-grown age (Rohmatullayaly et al. 2017). This phenotype is apparent in comparison to Bogor and American girls (Figure 2). Bogor is urban population of Sundanese (Suhartini 2007) that is the main tribe of Baduy, while American data is from Frisch and Revelle (Frisch and Revelle 1969, 1971a,b; Frisch 1975) who provided the original hypothesis on the relationship between fat and sexual maturity. The age-related changes in proportion of PBF, BW, and BH to their adult magnitudes were used to avoid differences in
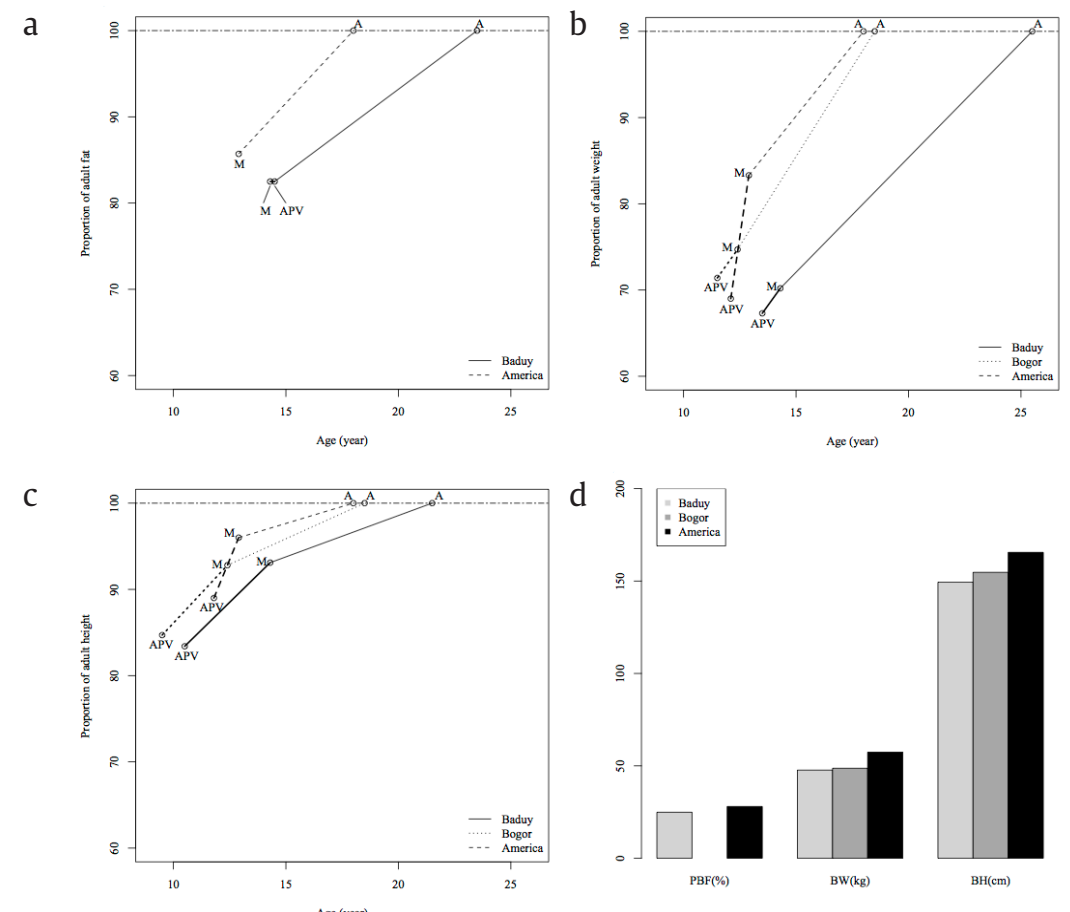

Figure 2. Body sizes at APV and age at menarche in proportion to full-grown. (a,b,c). Growth trajectory of Baduy girl is distinct from that of America and Bogor girls, while both of the later overlap. Compare to the two populations, Baduy girl is smaller in adult body size with later ages at spurt, menarche and full-grown. (d) Body size at full-grown. A age at growth velocity equals zero, APV age at peak velocity, $\mathrm{BH}$ body height, BW body weight, $\mathrm{PBF}$ percentage of body fat to total body weight, $\mathrm{M}$ age at menarche. Sources: Bogor, Suhartini (2007); America, Frisch and Revelle (1969; 1971a,b; 1975). 
methods to measure the magnitudes (Figure 2a-c). Adult sizes of PBF, BW, and BH of Baduy girls were smaller (Figure 2d) and at APV and age at menarche the bodily proportions were also lower (Figure 2ac) than the two populations. It should be noted that the long time it took to complete the growth was accomplished by slow rate with low spurt. This life history efficiently economizes body growth and maintenance in facing low caloric and/or protein availability (Frisch and Revelle 1971b; Frisch 1975; Walker et al. 2006; Urlacher et al. 2016). Beside poor nutrition, several studies showed that high physical activity (Walker et al. 2006; Ajita and Jiwanjot 2014) also influenced the bodily growth. Baduy people work their swidden farm for eight months in a year (Ichwandi and Shinohara 2007) and their children start to learn farming at age 10 year (Erwinatu 2012). The condition of hilly terrain with average slope of $49.1 \%$ (Ichwandi and Shinohara 2007) and working with only manual tools require intense physical exercise. However, the demandingly high activity was not met by adequate nutrition. A measurement in 1983 found that average energy intake of an adult Baduy male at $2517 \mathrm{kcal}$ was lower than energy he expended at $2935 \mathrm{kcal}$ per day (Hestiwati 1983). There is no data on female energy requirement; however, the general condition of caloric depletion in male may also be the same for female. Moreover, juveniles below-five-yearold boys and girls were reported to get energy and protein intakes about $1125 \mathrm{kcal}$ and $21 \mathrm{~g}$ per capita per day, which were lower than recommended dietary allowances (Sukandar and Mudjajanto 2009).

In summary, poor nutrition and high physical activity elicited principle of ontogenetic allometry to synchronize the acceleration and deceleration of growths in body linearity and body ponderality whereby growth in body height functioned to reach the body size target and to provide skeletal framework for development of body mass. The biocultural conditions lead to slow bodily growth rate with low spurt resulting in the characteristics of Baduy girl that was small in size and late in both sexual maturity and full-grown ages.

\section{Acknowledgements}

We thank to Mr. Jaro Dainah (former head of Kanekes village) for guiding our research. We also thank to Mr. Saidam and his family, Mr. Marsadi (deceased) and his family, Ms. Eros, and all subjects for help during data sampling. A part of this research was funded by LPDP 2013 (Ministry of Finance, Indonesia) for E.N.R dissertation fund. The first author benefited from Beasiswa Unggulan 2012 (Ministry of Education and Culture, Indonesia) for PhD scholarship.

\section{References}

Adair LS. 2001. Size at birth predicts age at menarche. Pediatrics 107:1-7.

Ajita A, Jiwanjot J. 2014. Overweight and physical activity as a measure of age at menarche in females. Am J Sports Med 2:32-34.

Bogin B. 1999. Pattern of Human Growth. $2^{\text {nd }}$ ed. Cambridge: Cambridge Univ Pr.

Chang SH et al. 2000. Height and weight change across menarche of schoolgirls with early menarche. Arch Pediatr Adolesc Med 154:880-884.

Day SJ, Lawrence PA. 2000. Measuring dimensions: The regulation of size and shape. Development 127:29772987.

Ebling FJP. 2005. The neuroendocrine timing of puberty. Reproduction 129:675-683.

Ellison PT. 1981. Prediction of age at menarche from annual height increments. Am J Phys Anthropol 56:71-75.

Ellison PT. 1982. Skeletal growth, fatness, and menarcheal age: A comparison of two hypotheses. Hum Biol 2:269-281.

Erwinantu. 2012. Saba Baduy Sebuah Perjalanan Wisata Budaya Inspiratif. Jakarta: PT Gramedia Pustaka Utama.

Eveleth PB, Tanner JM. 1990. Worldwide Variation in Human Growth. $2^{\text {nd }}$ ed. Cambridge: Cambridge Univ Pr.

Fechner PY. 2002. Gender Differences in Puberty. J Adolesc Health 30S:44-48.

Frisch RE, McArthur JW. 1974. Menstrual cycles: Fatness as a determinant of minimum weight for height necessary for their maintenance or onset. Science 185:949-951.

Frisch RE et al. 1973. Components of weight at menarche and the initiation of the adolescent growth spurt in girls: Estimated total water, lean body weight, and fat. Hum Biol 45:469-483.

Frisch RE, Revelle R. 1969. The height and weight of adolescent boys and girls at the time peak velocity of growth in height and weight: Longitudinal data. Hum Biol 41:536-559.

Frisch RE, Revelle R. 1970. Height and weight at menarche and a hypothesis of critical body weight and adolescent events. Science 169:397-398.

Frisch RE, Revelle R. 1971a. The height and weight of girls and boys at the time of initiation of the adolescent growth spurt in height and weight and the relationship to menarche. Hum Biol 43:140-159.

Frisch RE, Revelle R. 1971b. Height and weight at menarche and a hypothesis of menarche. Arc Dis Child 46:695701.

Frisch RE. 1972. Weight at menarche: Similarity for wellnourished and undernourished girls at differing ages and evidence for historical constancy. Pediatrics 3:445-450.

Frisch RE. 1975. Demographic implication of the biological determinants of female fecundity. Biodemography Soc Biol 22:17-22.

Gould SJ. 1966. Allometry and size in ontogeny and phylogeny. Biol Rev 41:587-640.

Gurven M, Walker R. 2006. Energetic demand of multiple dependents and the evolution of slow human growth. Proc $R$ Soc B 273:835-841.

Hasman D, Reis F. 2012. Urang Kanekes, Baduy People. Jakarta: Indonesian Heritage Society.

Hestiwati D. 1983. Pola produksi dan konsumsi pangan keluarga masyarakat Baduy Dalam dan Baduy Luar di Desa Kanekes, Kecamatan Leuwidamar, Kabupaten Lebak, Jawa Bara [Thesis]. Bogor: Institut Pertanian Bogor. 
Ichwandi I, Shinohara T. 2007. Indigenous practices for use of and managing tropical natural resources: a case study on Baduy community in Banten, Indonesia. Tropics 16:87-102.

Iskandar J, Ellen R. 1999. In situ conservation of rice landraces among the Baduy of West Java.J Ethnobiol 19:97-125.

Iskandar J, Iskandar BS. 2015. Makalahutama: Studi etnobotani keanekaragaman tanaman pangan pada "Sistem Huma" dalam menunjang keamanan pangan Orang Baduy. Pros Sem Nas Biodiv Indon 6:1265-1272.

Kaplan $\mathrm{H}$ et al. 2000. A theory of human life history evolution: diet, intelligence, and longevity. Evol Anthropol 9:156-185.

Kaplowitz PB. 2008. Link between body fat and the timing of puberty. Pediatrics 121:S208-S216.

Karapanou O, Papadimitriou A. 2010. Determinants of menarche. Reprod Biol Endocrinol 8:1-8.

Kawulur EIJJK et al. 2012. Association of sexual maturation and body size of Arfak children. HAYATI J Biosci 19:124-130.

Kawulur EIJJK et al. 2013. Pola pertumbuhan fisik pada anakanak Suku Arfak Papua Barat. Makara Seri Kesehatan 17:41-48.

Kramer KL, Greaves RD. 2010. Synchrony between growth and reproductive patterns in human females: early investment in growth among Pumé Foragers. Am J Phys Antrhropol 141:235-244.

Lecuit T, Le Goff L. 2007. Orchestrating size and shape during morphogenesis. Nature 450:189-192.

Malina RM et al. 2004. Growth, Maturation, and Physical Activity. United State of America: Human Kinetics.

Matkovic V et al. 1997. Leptin is inversely related to age at menarche in human females. J Clin Endocrinol Metab 10:3239-3245.

Migliano AB et al. 2007. Life history trade-offs explain the evolution of human Pygmies. PNAS 104:2021620219.
R Development Core Team. 2016. R: A Language and Environment for Statistical Computing Vienna: $\mathrm{R}$ Foundation for Statistical Computing.

Rogol AD et al. 2000. Growth and pubertal development in children and adolescents: effects of diet and physical activity. The American Journal of Clinical Nutrition 72:521S-521S.

Rohmatullayaly EN et al. 2017. Growth Pattern of Body Size in Baduy People. HAYATI J Biosci 24:57-64.

Slaughter $\mathrm{MH}$ et al. 1988. Skinfold equation for estimation of body fatness in children and youth. Hum Biol 60:709-723.

Sprent P. 1972. The Mathematics of size and shape. Biometrics 28:23-37.

Stasinopoulos DM, Ridby RA. 2007. Generalized additive models for location scale and shape (GAMLSS) in R. J Stat Software 23:1-64.

Suhartini. 2007. Tahap-tahap kematangan seksual perempuan di wilayah Bogor [Thesis]. Bogor: Fakultas Matematika dan Ilmu Pengetahuan Alam, Institut Pertanian Bogor.

Sukandar D, Mudjajanto ES. 2009. Kebiasaan dan konsumsi pangan Suku Baduy. Jurnal Gizi dan Pangan 4:51-62.

Urlacher SS et al. 2016. Physical growth of the Shuar: Height, weight, and BMI References for an Indigenous Amazonian population. Am J Hum Biol 28:16-30.

Venables WN, Ripley BD. 1999. Modern applied statistics with S-Plus. New York: Springer Inc.

Walker $\mathrm{R}$ et al. 2006. Growth rates and life histories in twenty-two small-scale societies. Am J Hum Biol 18:295-311.

Wessing R, Barendregt B. 2005. Tending the spirit's shrine: Kanekes and Pajajaran in West Java. Moussons:3-26. 